\title{
Purification and evaluation for effects of temperature on extracellular xylanase activity from Aspergillus oryzae DSM 1863
}

\author{
Tinh sạch và đánh giá ảnh hưởng của nhiệt độ lên hoạt tính enzyme xylanase \\ ngoại bào của chủng Aspergillus oryzae DSM 1863
}

Research article

Do Thi Tuyen*, Nguyen Sy Le Thanh, Nguyen Thi Thao

Institute of Biotechnology, Vietnam Academy of Science and Technology, 18 Hoang Quoc Viet, Hanoi, Vietnam

\begin{abstract}
Xylanase was purified from the crude culture of Aspergillus oryzae DSM1863 by sephadex G200 and DEAE - cellulose ion exchange chromatography. The molecular mass of the purified xylanase determined by SDS-PAGE was $21 \mathrm{kDa}$ with a specific activity of $6768 \mathrm{U} / \mathrm{mg}$ towards $1 \%(\mathrm{w} / \mathrm{v})$ of birch wood xylan. The optimum temperature was observed at $60^{\circ} \mathrm{C}$. The enzyme was thermostable in the temperature range of $37-50^{\circ} \mathrm{C}$ with a high residual activity of $62-74 \%(650.6-775.9 \mathrm{U} / \mathrm{mg}$ protein).
\end{abstract}

Enzyme xylanase được tinh sach tì dịch lên men của chủng Aspergillus oryzae DSM1863 sau khi qua cột sắc ký lọ gel sephadex G200 và sắc ký trao đổi ion DEAE-cellulose. Khối luợng phân tủ của enzyme xylanase tinh sạch được xác định bằng điên di đồ SDS-PAGE. Xylanase tinh sạch có kich thước là $21 \mathrm{kDa}$ với hoạt tính đặc hiệu đạt $6768 \mathrm{U} / \mathrm{mg}$ sau khi được xác định với nồng độ co chất là $1 \%$ birch wood xylan. Nhiệt độ tối ưu để enzyme hoạt động mạh nhất là $60^{\circ} \mathrm{C}$. Enzyme xylanase khá bền nhiệt. Hoạt tính của enzyme vẫn còn duy trì 62-74\% (hoạt tính đặc hiệu đạt 650.6$775.9 \mathrm{U} / \mathrm{mg}$ protein) sau khi 8 giò ủ ỏ $37-50^{\circ} \mathrm{C}$.

Keywords: Aspergillus oryzae DSM1863, purification, temperature, xylanase

\section{Introduction}

Xylan is a major ingredient of the hemicellulose complex. To hydrolyze xylan, the cooperative action of several enzymes of different functions is necessary. The enzyme involved in the degradation of main polysaccharide chain are endo-1,4- $\beta$-D-xylanase (EC 3.2.1.8) randomly cleaving the xylan backbone, $\beta$-D-xylosidase (EC3.2.1.37) cleaving xylose monomers from the non-reducing end of xylooligosaccharides. The removal of side groups is catalysed by $\alpha-\mathrm{L}$ arabinofuranosidases (EC 3.2.1.55), $\alpha$-D-glucuronidases (EC 3.2.1.139), acetylxylan esterases (EC 3.1.1.72), ferulic acid esterases (EC 3.1.1.73) and p-coumaric acid esterases (EC 3.1.1.-) (Collins et al., 2005).

Endoxylanase plays a key role in xylan hydrolysis and have applications in various industries including pulp (Zhao et al., 2006; Ayyachamy and Vatsala, 2007), bread making (Jiang et al., 2005; Romanowska et al., 2006), brewery , beverage (Polizeli et al., 2005), xylitol, feed enzyme
(Khandeparker and Numan, 2008). Xylanase is used for pulp industry as it supports the bleaching process, reduce the toxic chemicals (chlorine) used to bleach lignin contained in the paper. Other important applications of xylanase are to make the bread fine and soft and extend the storage time; to purify fruit juice, wine and beer; and to form xylitol glucose used in confectionary industry. In the breeding, xylanase expedites the digestion process of food containing xylan and at the same time helps to reduce the viscosity in the digestive system and follow by many positive effects such as improved food absorption, improved microorganism of the intestine in the advantageous direction, reduced digestion disorder and drier excrement (Bernier et al., 1983).

A variety of microbes, including bacteria, yeast and filamentous fungi, has been reported to produce xylanases, in which the most potent producers are fungi (Haltrich et al., 1996). A number of xylanases have been purified from a wide variety of microbes such as Bacillus strains (Bernier et al., 1983; Panbangred et al., 1985; Ayyachamy and 
Vatsala, 2007) and Aspergillus strains (Fernandez-Espinar et al., 1994; Fialho and Carmona, 2004; Krisana et al., 2005; Lu et al., 2008; Nair et al., 2008). However, xylanases are produced mainly by Aspergillus and Trichoderma sp. on an industrial scale. The fungus Aspergillus oryzae has been used in the tradition food industry of Japan for over 1000 years. As A. oryzae has been long used in food production, it is considered as a safe fungus and certified by World Health Organization (Machida, 2002). $A$. oryzae is able to secrete a large amount of enzyme in the environment. This property has been used in the commercial production for recombined enzyme and natural enzyme of $A$. oryzae. Many types of recombined protein are generated in submerged culture medium; however, in solid fermenting medium, A. oryzae as well as other types of fungus, is able to generate a large amount of enzyme which is higher than that generated in the submerged culture medium. In Japan, many types of commercial enzyme have been produced by solid fermentation as well as by conventional fermentation (Tsuchiya et al., 1994).

Here, we purified and characterization of xylanase from $A$. oryzae DSM1863. We also identified the optimum temperature and thermostable of the purified xylanase. The biochemical characteristics suggested that the xylanase has a potential application, including use as a feed enzyme.

\section{Materials and methods}

\subsection{Strain and culture conditions}

The Aspergillus oryzae DSM1863 purchased from the German Microorganism Collection Center (DSMZ) was grown on the liquid medium containing $2 \mathrm{~g} / 1 \mathrm{NaNO}_{3} ; 1 \mathrm{~g} / \mathrm{L}$ $\mathrm{K}_{2} \mathrm{HPO}_{4} ; 0.5 \mathrm{~g} / \mathrm{L} \mathrm{MgSO}_{4} ; 0.5 \mathrm{~g} / \mathrm{L} \mathrm{KCl} ; 10 \mathrm{~g} / \mathrm{L}$ soybean powder; $40 \mathrm{~g} / \mathrm{L}$ corn cobs; $\mathrm{pH}$ 7.0. The inoculated flasks were incubated for 4 days at $30^{\circ} \mathrm{C}$ on a rotary shaker at 200 rpm.

\subsection{Chemicals}

Birch wood xylan was purchased from Biochemika; 3.5dinitrosalicylic acid (DNS) from Fluka. Sephadex G200 and DEAE- cellulose were supplied by Pharmacia Co. (GE Healthcare. SDS was supplied Sigma Aldrich Co. (St, Louis, USA). Agar, soybean powder and corn cobs were from Biotech (Vietnam). NaHPO $\mathrm{MgSO}_{4}$ were from BioBasic Inc (Ontario, Canada). All other chemicals were of analytical grade unless otherwise stated.

\subsection{Method}

\subsubsection{Xylanase purification}

The culture was centrifuged for $10 \mathrm{~min}$, at $8000 \mathrm{xg}$. Four $\mathrm{ml}$ of the crude enzyme extract (114.3 units) was applied to a Sephadex G-200 column $(2.6 \times 6 \mathrm{~cm})$ pre-equilibrated with $50 \mathrm{mM}$ potassium phosphate buffer $\mathrm{pH} 7.5$ at a flow rate of $25 \mathrm{ml} / \mathrm{h}$ then washed with the same buffer. The eluate was collected with $18 \mathrm{ml}$ per fraction. A highly active xylanase pool of $5 \mathrm{ml}$ through Sephadex G-200 column was further applied to a DEAE-cellulose ion exchange chromatography pre-equilibrated with $50 \mathrm{mM}$ Tris $\mathrm{HCl}$ buffer $\mathrm{pH} 8.0$ containing $50 \mathrm{mM} \mathrm{NaCl}$ (buffer A), then washed with the same buffer. The protein was eluted with $50 \mathrm{mM}$ Tris $\mathrm{HCl}$ buffer $\mathrm{pH} 8.0$ containing $1000 \mathrm{mM} \mathrm{NaCl}$ (buffer B) at a flow rate of $20 \mathrm{ml} / \mathrm{h}$ until $\mathrm{OD}_{280 \mathrm{~nm}}<0.010$. The eluate was collected with $7.5 \mathrm{ml}$ per fraction. The fractions containing highly active xylanase activity were pooled and used as purified enzyme for characterization. All purification steps were carried out at $4^{\circ} \mathrm{C}$, unless otherwise specified.

\subsubsection{Xylanase activity estimation}

Xylanase activity was determined by measuring an increase of concentration of reducing sugars produced by enzymatic hydrolysis of birchwood xylan. A reaction mixture of $100 \mu \mathrm{l}$ of the crude or purified xylanase containing 0.1 $\mu \mathrm{g}$ total protein was incubated with $400 \mu \mathrm{l}$ of $0.5 \%$ (w/v) birch wood xylan in $20 \mathrm{mM}$ potassium phosphate buffer $\mathrm{pH} 6.5$ at $55^{\circ} \mathrm{C}$ for $5 \mathrm{~min}$. To arrest the reducing sugar released in the reaction mixture, $1.25 \mathrm{ml}$ of 3.5,-dinitrosalicylic acid (DNS) was added. The reduced sugars were determined by measuring the absorbance at $540 \mathrm{~nm}$ (Miller, 1959). D-xylose was used as standard. One unit (IU) of xylanase activity was defined as the amount of enzyme that released $1 \mu \mathrm{mol}$ of xylose per min under the standard assay conditions. All measurements were carried out three times and from these values the average value was taken.

\subsubsection{SDS-PAGE and protein concentration}

SDS polyacrylamide gel electrophoresis (SDS-PAGE) was carried out as described by Laemmli (Laemmli, 1970) with Bio-Rad equipment. SDS-PAGE was usually performed on gels containing $12.5 \%(\mathrm{w} / \mathrm{v})$ acrylamide according to the manufacture's recommendation. The gels were stained with Coomassie Brilliant Blue R- 250 for protein. Protein was estimated by the method of Braford with the bovine serum albumin as standard (Bradford, 1976).

\subsubsection{Effects of temperature on xylanase activity and thermostability}

To investigate the effect of the reaction temperature on the xylanase activity, $100 \mu \mathrm{l}$ of the purified enzyme $(0.1 \mu \mathrm{g}$ protein) was incubated together with $400 \mu \mathrm{l}$ of $0.5 \%$ (ww/v) of birch wood xylan in $20 \mathrm{mM}$ potassium phosphate buffer $\mathrm{pH} 6.5$ at different temperatures $37^{\circ} \mathrm{C} ; 40^{\circ} \mathrm{C}$; $45^{\circ} \mathrm{C} ; 50^{\circ} \mathrm{C} ; 55^{\circ} \mathrm{C} ; 60^{\circ} \mathrm{C}$, and $70^{\circ} \mathrm{C}$ for $5 \mathrm{~min}$ and then the reducing sugars were arrested by addition of $1.25 \mathrm{ml}$ DNS reagent. To study the thermostability of the enzyme, $10 \mu \mathrm{l}$ of the purified xylanase $(0.1 \mu \mathrm{g}$ protein $)$ were incubated at temperatures ranging from $37^{\circ} \mathrm{C} ; 50^{\circ} \mathrm{C} ; 60^{\circ} \mathrm{C}$ to $70^{\circ} \mathrm{C}$ for different intervals of time before using it for assay.

\section{Results}

\subsection{Purification of xylanase}

The xylanase production by $A$. oryzae DSM1863 in the mineral medium was $114.3 \mathrm{U} / \mathrm{ml}$ (specific activity of $615.04 \mathrm{U} / \mathrm{mg}$ protein) after 72 hours of cultivation. This culture supernatant was applied to Sephadex G-200 and DEAE- cellulose chromatography. The pooled Sephadex G-200 fractions containing high xylanase activity (3768 
$\mathrm{IU} / \mathrm{mg}$ ) were applied further to the DEAE- cellulose ion exchange chromatography (Fig. 2). The xylanase was purified with a factor of 11 and a yield of $28 \%$. The purified enzyme gained a specific activity of $6768 \mathrm{IU} / \mathrm{mg}$ (Tab. 1) and showed a unique protein band on SDS-PAGE (Fig. 2). The molecular weight of this protein was estimated to be $21.0 \mathrm{kDa}$.

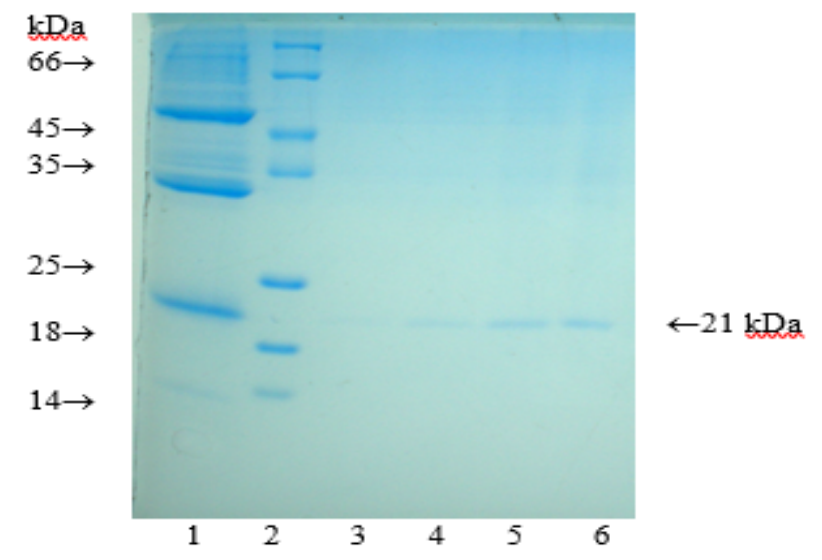

Figure 1. SDS-PAGE of the purified xylanase from $\boldsymbol{A}$. oryzae DSM1863 through Sephadex G-200 and DEAEcellulose (lane 1: the crude enzyme; lane 2: molecular weight marker; lane 3-6: the fractions were purified.

Nair et al (2008) purified two xylanases I and II from crude culture filtrate of $A$. sydowii SBS45 through a three-step purification scheme involving ammonium sulfate precipitation, gel filtration chromatography (Sephadex G-200), and anion exchange chromatography (DEAE-Sephadex A50). Xylanase I and II were purified 93.41 and 77.40 times with yields of 4.49 and 10.46 , respectively and had molecular weights of 20.1 and $43 \mathrm{kDa}$, respectively on SDSPAGE.

Lu et al. (2008) purified a xylanase from A. ficuum AF-98 throughout the precipitation with $50-80 \%\left(\mathrm{NH}_{4}\right)_{2} \mathrm{SO}_{4}$, DEAE-Sephadex A-50 ion exchange chromatography and Sephadex G-100 chromatography. The extracellular xylanase from this fungal was purified 32.6-fold to homogeneity and had a specific activity of $289 \mathrm{U} / \mathrm{mg}$ protein and showed a monomeric protein with a molecular mass of 35 $\mathrm{kDa}$ as determined by SDS-PAGE (Lu et al., 2008).

Fialho and Carmona (2004) also obtained two proteins with molecular weight of $21 \mathrm{kDa}$ and $24 \mathrm{kDa}$ during the purification of xylanase from $A$. giganteus using ammonium sulfate and Sephadex G-75. The purified xylanase from $A$. nidulans showed a single band on SDS-PAGE with a molecular mass of $34 \mathrm{kDa}$ and had an isoelectric point of approximately 3.4 (Fernandez-Espinar et al., 1994). The xylanase from Aspergillus cf. niger was purified using DEAE Sepharose and Phenyl Sepharose 6 Fast Flows to a homogeneity and showed a molecular mass of $21 \mathrm{kDa}$ (Krisana et al., 2005). An extracellular 22-kDa xylanase produced by Aspergillus sp. FP-470 strain was purified 30-fold (Camacho and Aguilar, 2003).

Table 1. Purification of xylanase from Aspergillus oryzae DSM1863

\begin{tabular}{lllllll} 
Steps & $\begin{array}{l}\text { Total } \\
(\mathrm{mg} / \mathrm{ml})\end{array}$ & protein & $\begin{array}{l}\text { Total } \\
\mathrm{U} / \mathrm{ml}\end{array}$ & $\begin{array}{l}\text { activity } \\
(\mathrm{U} / \mathrm{mg})\end{array}$ & $\begin{array}{l}\text { Specific } \\
\text { factor }\end{array}$ & $\begin{array}{l}\text { Yivity } \\
(\%)\end{array}$ \\
\hline Crude enzyme & 0.1858 & 114.3 & 615.04 & 1 & 100 \\
Sephadex G200 & 0.0212 & 78.7 & 3768 & 6.13 & 43 \\
DEAE-Sephadex & 0.0126 & 84.3 & 6768 & 11 & 28
\end{tabular}

\subsection{Optimum temperature and thermostabil- ity}

The xylanase from $A$. oryzae DSM1863 acted in a large temperature range from $40^{\circ} \mathrm{C}$ to $70^{\circ} \mathrm{C}$. The xylanase activity increased gradually from $82 \%(744.6 \mathrm{U} / \mathrm{mg})$ at $40^{\circ} \mathrm{C}$ to the maximum of $100 \%(903.1 \mathrm{U} / \mathrm{mg})$ at $60^{\circ} \mathrm{C}($ Fig. 2$)$ and then decreased gradually to $82 \%(738.3 \mathrm{U} / \mathrm{mg})$ at $70^{\circ} \mathrm{C}$. The temperature treatment from $37^{\circ} \mathrm{C}$ to $70^{\circ} \mathrm{C}$ for $1-8$ hours showed an obvious temperature effect on the xylanase stability. The xylanase from $A$. oryzae DSM1863 possessed a thermostability in a temperature range $37-50^{\circ} \mathrm{C}$.

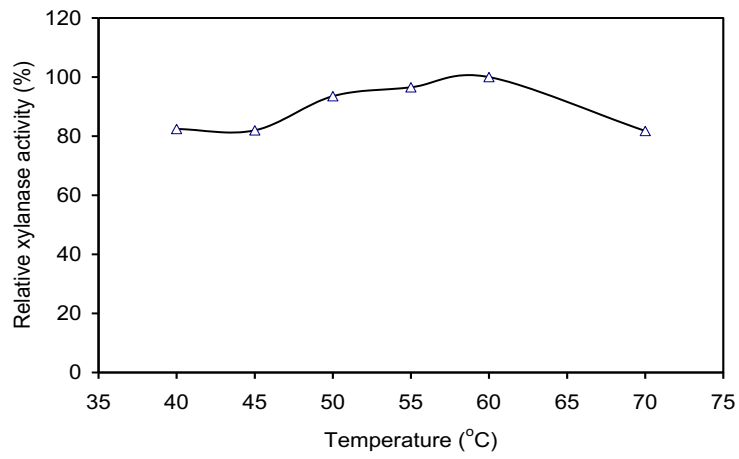

Figure 2. Effect of temperature on xylanase activity 


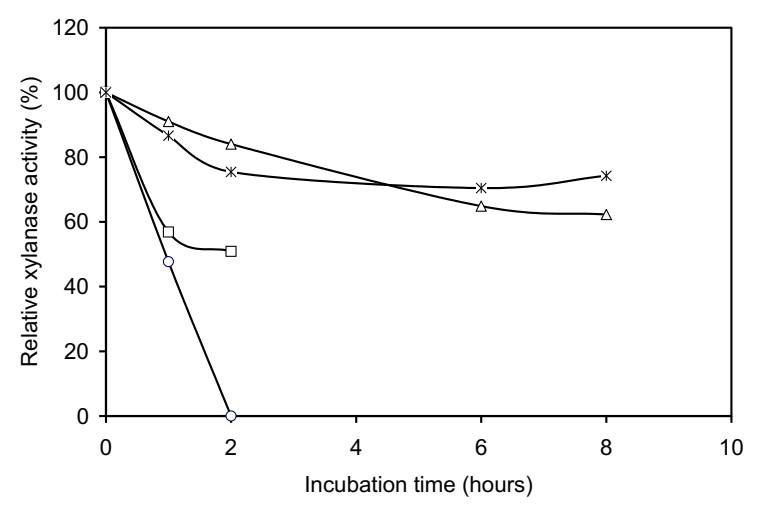

Figure 3. Effect of stability temperature on xylanase activity (rhombus: $70^{\circ} \mathrm{C}$; squares: $60^{\circ} \mathrm{C}$; triangles: $50^{\circ} \mathrm{C}$; stars: $37^{\circ} \mathrm{C}$ )

The residual activity profiles of the xylanase treated at $37^{\circ} \mathrm{C}$ and $50^{\circ} \mathrm{C}$ were quite similar (Fig. 3). The residual xylanase activity decreased gradually to $62 \%(650.6 \mathrm{U} / \mathrm{mg})$ and $74 \%(775.9 \mathrm{U} / \mathrm{mg})$ for 8 hours of the temperature treatment at $50^{\circ} \mathrm{C}$ and $37^{\circ} \mathrm{C}$, respectively, whereas the xylanase activity lost one half when it was treated just for 1 or 2 hours at $70^{\circ} \mathrm{C}$ or $60^{\circ} \mathrm{C}$, respectively.

The xylanase from various Aspergillus strains had different optimum temperatures however the optimum temperatures ranged from $45^{\circ} \mathrm{C}$ to $60^{\circ} \mathrm{C}$. The optimum temperature was $60^{\circ} \mathrm{C}$ (XynF1 from $A$. oryzae (Kitamoto et al., 1999)), $55^{\circ} \mathrm{C}$ (endo-1,4- $\beta$-xylanase $\mathrm{B}$ from Aspergillus cf. niger BCC14405)(Krisana et al., 2005), $50^{\circ} \mathrm{C}$ ( xylanase from $A$. giganteus) (Fialho and Carmona, 2004), the xylanase I and II from A. sydowii SBS 45 (Nair et al., 2008), $45^{\circ} \mathrm{C}$ (xylanase from $A$. ficuum AF-98 (Lu et al., 2008).

\section{Conclusions}

A xylanase was purified from the culture supernatant of $A$. oryzae DSM1863 throughout Sephadex G-200 chromatography and DEAE-cellulose ion exchange chromatography. The purified xylanase showed a specific activity of 6768 $\mathrm{IU} / \mathrm{mg}$ protein and a protein band of about $21 \mathrm{kDa}$ on SDSPAGE. The enzyme showed the optimum temperature was observed at $60^{\circ} \mathrm{C}$. The purified xylanase was stable in the temperature range $37-50^{\circ} \mathrm{C}$.

\section{Acknowledgement}

The study was supported by the Priority Program of Development and Application of Biotechnology in Agriculture and Rural Development Towards 2020, Vietnam Ministry of Agriculture and Rural Development, 2007-2010 (Project: Production and application of highly qualitive multienzyme products by recombined microbes to improve the effective use of animal food). The authors are thankful Prof. Quyen Dinh Thi for guidance.

\section{References}

[1] Ayyachamy M, Vatsala TM (2007) Production and partial characterization of cellulase free xylanase by
Bacillus subtilis $\mathrm{C} 01$ using agriresidues and its application in biobleaching of nonwoody plant pulps. Lett Appl Microbiol 45:467-472.

[2] Bernier RJ, Desrochers M, Jurasek L, Paice MG (1983) Isolation and characterization of a xylanase from Bacillus subtilis. Appl Environ Microbiol 46:511-514

[3] Bradford MN (1976) A rapid and sensitive method for the quantitation of microgram quantities of protein utilizing the principle of protein-dye binding. Anal Biochem 72:248- 254

[4] Camacho NA, Aguilar OG (2003) Production, purification, and characterization of a low-molecular-mass xylanase from Aspergillus sp. and its application in baking. Appl Biochem Biotechnol 104(3):159-172.

[5] Collins T, Gerday C, Feller G (2005) Xylanases, xylanase families and extremophilic xylanases. FEMS Microbiol Rev 29:3-23.

[6] Fernandez-Espinar M, Pinaga F, Graaff Ld, Visser J, Ramon D, Vallds S (1994) Purification, characterization and regulation of the synthesis of an Aspergillus nidulans acidic xylanase. Appl Microbiol Biotechnol 42:555-562.

[7] Fialho MB, Carmona EC (2004) Purification and characterization of xylanases from Aspergillus giganteus. Folia Microbiol 49:13-18.

[8] Haltrich D, Nidetzky B, Kulbe KD, Steiner W, Zupancic S (1996) Production of fungal xylanases. Bioresour Technol 58:137-161.

[9] Jiang ZQ, Yang SQ, Tan SS, Li LT, Li XT (2005) Characterization of a xylanase from the newly isolated thermophilic Thermomyces lanuginosus CAU44 and its application in bread making. Lett Appl Microbiol 41:69-76.

[10] Kitamoto N, Yoshino S, Ohmiya K, Tsukagoshi N (1999) Purification and characterization of the overexpressed Aspergillus oryzae Xylanase, XynF1. Biosci Biotechnol Biochem 63:1791-1794.

[11] Krisana A, Rutchadaporn S, Jarupan G, Lily E, Sutipa T, K. K (2005) Endo-1,4- $\beta$-xylanase B from Aspergillus cf. niger BCC14405 isolated in Thailand: Purification, characterization and gene isolation. J Biochem Mol Biol 38:17-23.

[12] Khandeparker R, Numan MT (2008) Bifunctional xylanases and their potential use in biotechnology. J Ind Microbiol Biotechnol 35:635-644.

[13] Laemmli UK (1970) Cleavage of structure proteins during the assembly of the head of bacteriophage T4. Nature 227:680- 685.

[14] Lu F, Lu M, Lu Z, Bie X, Zhao H, Wang Y (2008) Purification and characterization of xylanase from $\mathrm{As}$ pergillus ficuum AF-98. Bioresour Technol 99:59385941.

[15] Machida M (2002) Progress of Aspergillus oryzae genomics. Adv Appl Microbiol 51:81-106.

[16] Miller GL (1959) Use of dinitrosalicylic acid reagent for determination of reducing sugars. Anal Chem 


\section{$31: 426-428$.}

[17] Nair SG, Sindhu R, Shashidhar S (2008) Purification and biochemical characterization of two xylanases from Aspergillus sydowii SBS 45. Appl Biochem Biotechnol 149:229-243.

[18] Panbangred W, Fukusaki E, Epifanio EC, Shinmyo A, Okada H (1985) Expression of a xylanase gene of Bacillus pumilus in Escherichia coli and Bacillus subtilis. Appl Microbiol Biotechnol 22:259-264.

[19] Polizeli ML, Rizzatti AC, Monti R, Terenzi HF, Jorge JA, Amorim DS (2005) Xylanases from fungi: properties and industrial applications. Appl Microbiol Biotechnol 67:577-591.
[20] Romanowska I, Polak J, Bielecki S (2006) Isolation and properties of Aspergillus niger IBT-90 xylanase for bakery. Appl Microbiol Biotechnol 69:665-671.

[21] Tsuchiya K et al. (1994) High level secretion of calf chymosin using a glucoamylase-prochymosin fusion gene in Aspergillus oryzae. Biosci Biotechnol Biochem 58:895-899.

[22] Zhao J, Li X, Qu Y (2006) Application of enzymes in producing bleached pulp from wheat straw. Bioresour Technol 97:1470-1476. 